\title{
parallel convergences: thinking with biesta about philosophy and education
}

\author{
stefano oliverio ${ }^{1}$ \\ university of naples federico ii, italy
}

\section{abstract}

In this paper the question of the kind of dialogue that is possible between $\mathrm{P} 4 \mathrm{wC}$ and Gert Biesta's educational thinking is explored. The assumption - based also upon a reflection about the style of argumentation of Biesta when he addresses $\mathrm{P} 4 \mathrm{wC}-$ is that a dialogue is possible, despite the misgivings that he manifests about how $\mathrm{P} 4 \mathrm{wC}$ could end up merely turning into a broadened form of education for critical thinking. In order to investigate how this dialogue could look like, this response engages with what can represent a major bone of contention, namely the intimate bond between philosophy and education, which is pivotal in the $\mathrm{P} 4 \mathrm{wC}$ project and which, instead, Biesta seems to problematise, spotting in it the perpetuation of a kind of "mentalisation" plaguing much of the Western educational and philosophical tradition. After construing this radical challenge as a Levinasian move, the paper endeavours to show how $\mathrm{P} 4 \mathrm{wC}$ can be taught by it. In particular, it is argued that Biesta's concerns can help us to rediscover a specific view of what philosophising-together as sumphilosophein (to adopt an Aristotelian notion) may mean and to look at the community of philosophical inquiry as the site of the 'polemic commonality of philosophy and education.' While recognizing the points of contact and (possible) encounter with Biesta's ideas, the paper excludes any 'fusion of horizons' and proposes, instead, two other metaphors to capture the kind of dialogue which can go on.

keywords: sumphilosophein; community; community of philosophical inquiry; learnification; philosophy and education.

\section{convergências paralelas: pensando com biesta sobre filosofia e educação}

resumo

Neste artigo, a questão sobre o tipo de diálogo possível entre a filosofia para e com crianças e o pensamento educacional de Gert Biesta é explorada. A pressuposição baseada também na reflexão sobre o estilo de argumentação de Biesta quando ele se refere à filosofia para e com crianças - é que um diálogo é possível, a despeito das reservas que ele manifesta sobre como a filosofia para e com crianças poderia acabar se tornando uma mera forma mais abrangente de educação para o pensamento crítico. Para investigar com o quê este dialogo poderia se parecer, este texto se compromete com algo que pode representar uma grande fonte de discórdia, a saber, a ligação íntima entre filosofia e educação, que é central ao projeto da filosofia para e com crianças e que, ao contrário, Biesta parece problematizar, focando na perpetuação de uma espécie de "mentalização" contagiando grande parte da tradição educacional e filosófica ocidental. Depois de explicar este desafio radical como um movimento levinasiano, o artigo pretende mostrar como a filosofia para e com crianças pode ser ensinada através dele. Particularmente, é defendido que as preocupações de Biesta podem nos ajudar a redescobrir uma visão específica do que o filosofar-junto como "sumphilosophein" (para adotar uma noção aristotélica) pode significar, e olhar para a comunidade de questionamento filosófico como o lugar do "polêmico acordo entre filosofia e educação". Enquanto reconhece os

\footnotetext{
${ }^{1}$ E-mail: stefano.oliverio@unina.it
} 
pontos de contato e (possível) encontro com as ideias de Biesta, o artigo exclui qualquer "fusão de horizontes" e propõe, ao invés disso, duas outras metáforas para capturar o tipo de diálogo que pode perdurar.

palavras-chave: sumphilosophein; comunidade; comunidade de investigação filosófica; aprendização; filosofia e educação.

convergencias paralelas: pensando con biesta sobre filosofía y educación.

resumen

En este artículo es explorada la cuestión del tipo de diálogo posible entre filosofía con niños y el pensamiento educacional de Gert Biesta. El presupuesto - también basado en la reflexión sobre el estilo de argumentación de Biesta cuando él se refiere a la filosofía para y con niños- es que un diálogo es posible, a pesar de las reservas que manifiesta sobre cómo la filosofía para y con niños podría acabar volviéndose una mera forma más abarcativa de pensamiento crítico. Para investigar con qué este diálogo podría parecerse, este texto se compromete con algo que puede representar una gran fuente de desacuerdo, a saber, la íntima ligazón entre filosofía y educación, que es central para el proyecto de filosofía con y para niños y que, por el contrario, Biesta pretende problematizar, centrando la atención en la perpetuación de una "mentalización" contagiando gran parte de la tradición educacional y filosófica de occidente. Después de explicar este desafío radical como un movimiento levinasiano, el artículo pretende mostrar cómo la filosofía con y para niños puede ser enseñada a través de él. Particularmente se defiende que las preocupaciones de Biesta pueden ayudarnos a redescubrir una visión específica de lo que el "filosofar-junto" como "sumphilosophein" (para adoptar una noción filosófica) puede significar, y mirar a la comunidad de indagación filosófica como el lugar del "polémico acuerdo entre filosofía y educación". En cuanto reconoce los puntos de contacto y (posible) encuentro con las ideas de Biesta, el artículo excluye cualquier "fusión de horizontes" y propone, en lugar de eso, otras dos metáforas para capturar el tipo de diálogo que puede perdurar.

palabras clave: sumphilosophein; comunidad; comunidad de indagación filosófica; prendizaje; filosofía y educación. 
parallel convergences: thinking with biesta about philosophy and education

\section{attempts at a dialogue}

At the very core of this response there is a question: what kind of dialogue is possible between P4wC and Gert Biesta's educational thinking? ${ }^{2}$ I would like to take my cue from the particular style of argumentation that Biesta deploys when addressing $\mathrm{P} 4 \mathrm{wC}$, both in his recent speech in Madrid and in a previous contribution (BIESTA, 2011). In both cases, with some different nuances, he highlights the risk that $\mathrm{P} 4 \mathrm{wC}$ ends up turning into just one more programme in critical thinking and becoming accomplice with an instrumentalisation of philosophy in education, which could be not completely immune from some affinities with the trends of "learnification" ruling the contemporary educational scene (BIESTA, 2006, 2010, 2014, 2017a). While not concealing his misgivings and his perplexities, Biesta engages with $\mathrm{P} 4 \mathrm{wC}$ either through an "indirect argument" (see BIESTA, 2017b, p. 432; 449)3 or by specifying that his "aim is to suggest an additional rather than an alternative view about the educational use of philosophy" (BIESTA, 2011, p. 307).

\footnotetext{
${ }^{2}$ In a book chapter published in 2012 on contemporary challenges to P4C, I hinted at the need to "start [...] a dialogue and to work in the direction of an 'encounter' with Biesta [...]" (OLIVERIO, 2012a, p. 15, fn. 1). This response aspires to take a further step further in this direction.

${ }^{3}$ In quoting Biesta's Madrid presentation, I have drawn upon the PowerPoint through which Biesta spoke on that occasion. After completing this response, I also received the final version of Biesta's article (appearing in this same issue of Childhood \& Philosophy, with the presentation as appendix). I will refer to both as "BIESTA, 2017b". When the PowerPoint and the final article overlap, I am going to quote only the latter. However, I have decided to keep both references because, working on my response before receiving the final contribution, I insisted upon one phrase that has not been maintained in the article. Of course, one could argue that, if an author eliminates something when passing from the presentation to the full-blown article, this means that those aspects were only related to the occasion and context of a speech (for example for reasons of rhetorical effectiveness), not relevant for the argumentation as it is developed in a reflected-upon piece of writing, benefitting also from the discussion after the presentation. Accordingly, the eliminated formulations can be deemed to be marginal. I agree and I do not want to appear to be exaggerating the meaning of something that the author himself considered as dispensable. However, I can but hope that looking at the matter from these 'margins' could grant us some specific insights. Or to put it in a more pretentious way, I am inviting the reader (and the author of the main article for that matter) to look at the PowerPoint in terms of a kind of parergon (Derrida, 1979).
} 
I propose reading this language of 'indirectness' and of 'additionality' in terms of a willingness to dialogue. Biesta's aforementioned passage continues as follows:

This means that I do not have the ambition to suggest a new 'programme' for philosophy in education but rather wish to suggest a perspective that can act as a reminder of a different way in which one can 'engage' with philosophy-which in a sense can also be read as a reminder about how philosophy might 'engage' with us. (BIESTA, 2011, p. 307).

One could argue that Biesta is simply saying that he wants to play an entirely different game, which does not have anything in common with P4wC. In my idiosyncratic reading (which is admittedly, as a $\mathrm{P} 4 \mathrm{wC}$ practitioner, selfinterested), the choice of presenting his proposal as "additional" (as distinct from "alternative"4) could be construed as a sign of a readiness to open a space for dialogue, inviting the $\mathrm{P} 4 \mathrm{wC}$ community to look at the matter also and additionally from other viewpoints, and as showing interest in exploring the potentialities inherent in $\mathrm{P} 4 \mathrm{wC}$ practice. ${ }^{5}$

In other words, on this interpretation, while identifying certain risks in the way in which $\mathrm{P} 4 \mathrm{wC}$ is carried out, Biesta does not dismiss it as just one more constructivist pedagogy accessory to the dominant habitus of "learnification," but seems to be ready to see it as a possible interlocutor, if only in the sense of thinking together about education, childhood and philosophy, with the aim of finding new vocabularies to overturn the dominance of the "discourse of learning"

\footnotetext{
${ }^{4}$ It is to be noted that in the title of his article in this issue Biesta uses instead the adjective "alternative" to connote his outlook on philosophical work with children. This could be read as a radicalization of his distance from $\mathrm{P} 4 \mathrm{wC}$. I will assume, however, a substantial continuity in his stance towards $\mathrm{P} 4 \mathrm{wC}$. And the fact that the conclusion of his article (see below fn. 5), makes - at least implicitly - a distinction between an 'additional' and an 'alternative' approach to $\mathrm{P} 4 \mathrm{wC}$, may bear out this assumption.

5 The conclusion of Biesta's article in this issue could corroborate what I have called my 'idiosyncratic' reading of his 'indirect' and 'additional' style of argumentation: "Whether the second educational gesture is seen as a relevant dimension of and direction for education - I hesitate to call it an alternative paradigm - is a judgement I leave to the reader. From my perspective, I think that the existential approach to education I have tried to outline in this paper, provides an educational orientation that may well expand the reach and significance of philosophical work with children and young people beyond where much of this work currently seems to be located" (BIESTA, 2017b, p. 435. Emphasis added).
} 
(see BINGHAM, 2015). ${ }^{6}$ It is hardly necessary to say that postulating the possibility of a dialogue does not imply any warrant of a final synthesis or agreement. Actually, this is not even anticipated. What is important is the very fact of inhabiting this space of/for dialogue, and exploring its dimensions.

In his latest book - the fourth volume of his trilogy, as he humorously calls it - Biesta writes that the ideas offered there are "not just meant as ideas to think about - and hence to agree or disagree with - but perhaps first and foremost as ideas to think with" (BIESTA, 2017a, pos. 217). It is in this spirit that I will address some of his views in the following, principally in reference to the question of the community of philosophical inquiry (henceforth CPI). In my concluding remarks, I will return to the question from which I have taken my cue, and will offer two possible ways of framing the dialogue between P4wC and Biesta's thinking.

\section{the cpi in question}

In his speech in Madrid, Biesta stated from the very beginning that he was going to speak "as an outsider, outside of 'philosophical work with children,' outside of philosophy" (BIESTA, 2017b, p. 437). ${ }^{7}$ The climax of the sentence is not only rhetorically forceful but very revealing at the theoretical level. As I suggest interpreting him, Biesta did not confine himself to recognizing that he would not address the audience as an expert of $\mathrm{P} 4 \mathrm{wC}$ but, more fundamentally, that he would address them from without philosophy. He added that this would be the case because he considered himself "to be an educationalist," that is, one who asks "educational questions" (BIESTA, 2017b, p. 437). Finally, he specified that his misgivings about $\mathrm{P} 4 \mathrm{wC}$ are derived from a distancing from (Western) philosophy in its "analytical-logical" tradition, which blocks other possible (more

\footnotetext{
${ }^{6}$ Bingham's article was the key-speech in the ICPIC Conference of 2015. I might jokingly claim that one of the aims of this paper is to demonstrate the remarkable coherence of the last two ICPIC conferences, by comparing Bingham and Biesta's talks with each other. Indeed, the dialogue with Bingham and Biesta could help us to unearth (or, at least, to better thematise) some relevant aspects of $\mathrm{P} 4 \mathrm{wC}$ as an educational approach alien and opposed to learnification (see also OLIVERIO, forthcoming/2018).

7 This sentence does not appear in the final article, where Biesta only defines himself as "a relative outsider" (BIESTA, 2017b, p. 418).
} 
parallel convergences: thinking with biesta about philosophy and education

"phenomenological and speculative") approaches, and leads to educational practices privileging a "strongly conceptual and verbal" intercourse with the world, thus running a risk of a "mentalisation" (Biesta, 2017b, p. 418) of the educational endeavour. Although only introductory (and even cursory in the speech as a whole), these remarks are particularly important in understanding how Biesta's misgivings about $\mathrm{P} 4 \mathrm{wC}$ are rooted in a radical view of philosophy and the nature of its relationships with education.

I am going to engage with these concerns by understanding them as a Levinasian move, which I would like to approach indirectly. Adolpho Lingis (1994), the American translator of Levinas, characterises the emergence of Greek philosophy in terms of the substitution of the rational community for the existential encounter of the stranger qua stranger:

In the mercantile port cities of Greece, strangers arrive who ask the Greeks, Why do you do as you do? In all societies where groups of humans elaborate their distinctness, the answer was and is, because our fathers have taught us to do so, because our gods have decreed that it be so. Something new begins when the Greeks begin to give a reason that the stranger, who does not have these fathers and these gods, can accept. [...] The one who so answers commits himself to his statement, commits himself to supply a reason and a reason for the reason [...]. (LINGIS, 1994, pp. 3-4)

The establishment of the rational community is, accordingly, an operation of 'e-strangement'8 of the stranger, an erasing of her/his strangeness by building the conditions for a commonality of discourse. In this view, reason is an 'estrangement' from the existential plane, a shift from the 'indexicality' of the existential plenum to the domain of abstract symbols:

The rational community produces, and is produced by, a common discourse in a much stronger sense. The insights of individuals are formulated in universal categories, such that they are detached from the here-now index of the one who first formulated them. [...] Then, when any rational agent speaks, he speaks as a representative of the common discourse. (LINGIS, 1994, pp. 109-110)

Lingis reminds us, therefore, that

[b]efore the rational community, there was the encounter with the other, the intruder. The encounter begins with the one who exposes himself to

\footnotetext{
8 I am hyphenating the word to play with the etymology (the prefix ex-, which in Latin indicates a distancing from, and -strange) and to designate the movement through which the 'strangeness' is removed.
} 
the demand and contestation of the other. Beneath the rational community $[\ldots]$ is another community, the community that demands that the one who has his own communal identity, who produces his own nature, expose himself to the one with whom he has nothing in common, the stranger. (LINGIS, 1994, p. 10)

Biesta (2006) appropriates this distinction and inflects it in educational terms. He highlights "the role of schools and other educational institutions [...] in the constitution and reproduction of rational communities [...] Schools provide students with a very specific voice, namely, with the voice of the rational communities it represents through the curriculum" (BIESTA, 2006, pp. 56-57). And while not denying the importance of this 'function,' he warns us as educators that "we also shouldn't forget that this is not all that matters in life - and that it is perhaps even the case that what ultimately matters is not the reproduction of rational communities but the possibility for the other community to come and stay into existence" (BIESTA, 2006, p. 68).

Against this backdrop, one of the pillars of $\mathrm{P} 4 \mathrm{wC}$ seems to be in question: is the project of transforming our classrooms into CPIs merely the continuation of the modern project of building schools as rational communities by other means? Despite all the appeals to the recovery of the children's voices in their uniqueness, do CPIs work for an estrangement of those voices in their participation in the common discourse of reason? To mobilise Biesta's language in his Madrid address: by instantiating a Deweyan-Meadean form of communication, ${ }^{9}$ CPIs would, then, be the place where a child encounters the other just as someone with whom s/he is in communication and not as "someone who speaks to [her/him], who addresses [her/him], who touches [her/him], someone who asks for [her/him], or with a phrase from Levinas [...], who 'calls upon the unique in [her/him]'" (BIESTA, 2017b, p. 426; 444).

In cultivating the subjectivity of the one "who raises questions" CPIs would not be able to open up that space in which the "I is in question" - that is, the space in which subject-ness may come into existence (BIESTA, 2017a). Within this interpretive horizon, Biesta's vocabulary of "indirectness" and "additionality"

\footnotetext{
9 The explicit reference to Dewey's and Mead's notion of communication was eliminated in the final article.
} 
parallel convergences: thinking with biesta about philosophy and education

would be the sign that education as he invites us to see it can happen not within CPIs but only as their "interruption" and "suspension." His willingness to dialogue would consist, then, at the most in the recognition that CPIs may be beneficial in promoting rational communities along less traditional and more thought-provoking lines, by involving also other dimensions of thinking (e.g. creativeness and caring), which are usually neglected in other pedagogies, but he would insist that they comply with a traditional task of schooling and perpetuate the privilege of the being "in the head" (BIESTA, 2017b, p. 418; 438) instead of "existing in and with the world as subjects" (BIESTA, 2017b, p. 430). Such a 'fundamental' (= going to the very foundations of the $\mathrm{P} 4 \mathrm{wC}$ project) challenge would require a more elaborate discussion than is possible within the framework of this response. However, I am ready to admit that this is one way in which the dialogue between P4wC and Biesta could be framed.

On the other hand, I would like to hint at the possibility of another way of staying in a dialogue with Biesta. I do not aim at reaching any synthesis between the two 'perspectives' but only to indicate whether and how we can think with his ideas within the framework of CPI. Due to space constraints, I will confine myself to just one theme. ${ }^{10}$ In the wake of Masschelein and Simons (2013) characterisation of school as a "form of gathering," Biesta lays stress upon schools as places "where people come together" (BIESTA, 2017b, p. 419; 439) and this might help us to valorise the character of "togetherness" of CPIs, if only through a specific lens. Indeed, this does not mean emphasizing only an external feature of CPI but rather its intrinsic character: what happens (or, more cautiously, could or should happen) in CPI is a philosophizing-together as sumphilosophein. This expression comes from

\footnotetext{
10 Another important issue is the idea of grown-up-ness, which Biesta introduces in his latest book on teaching. On the one hand, I would tend to whole-heartedly endorse his appeal to an understanding of education in light of the notion of grown-up-ness viewed not from a developmentalist perspective but as "an existential quality or quality of existing" (BIESTA, 2017a, pos. 598). On the other, I would like to suggest that what the P4wC tradition could provide in a dialogue with Biesta is an understanding of childhood itself as an existential quality (see the works of Kennedy, Kohan and, more remotely, some insights of Gareth Matthews) and that this could be pivotal to complement and enrich Biesta's view of "the educational task [of teachers as] consist[ing] in making the grown-up existence of another human being in and with the world possible" (BIESTA, 2017a, pos. 402). However, this discussion must be postponed until another occasion.
} 
Aristotle's Nicomachean Ethics (IX, 12, 1172, a 1-7), where it is introduced, not within the framework of a theoretical discussion, but as an instance of the activities that friends love to do together. In this Aristotelian passage the semantic texture is dominated by an existential-perceptual vocabulary not a theoreticalconceptual one: Aristotle speaks of the "sensitive perception of oneself" (peri auton $d^{\prime} \bar{e}$ aisthēsis) as something "desirable" (airetē), which finds its actuality (energheia) in the living with each other (suzèn). Then he mentions the sumphilosophein as one of the ways in which all this may be achieved. In this perspective, through a hermeneutical permutation, we can state that sumphilosophein is not only (or primarily) a merely intellectual adventure but a living together, thanks to which one may attain a sense of oneself, which, as an aisthēsis, is not merely the outcome of the unfolding of the agency of the subject, ${ }^{11}$ but is experienced (also) as a form of 'passibility' (Roth, 2011) - a being-affected by and through co-existence with the others. ${ }^{12}$

I am not suggesting that the notion of sumphilosophein parallels the notion of existing in the world as a subject that Biesta (2017a) advocates; no fusion of horizons is invoked here. However, encountering the "resistance" of Biesta's misgivings about the 'verbalism' and 'conceptualism' of $\mathrm{P} 4 \mathrm{wC}$ practices reminds us that $\mathrm{P} 4 \mathrm{wC}$ should not be only (or predominantly) a merely intellectual enterprise, cultivating thinking skills, but (also and perhaps primarily) an existential event, in which children 'thoughtfully' live with friends (suzèn) by courtesy of whom they may undergo (rather than 'develop') the experience of sensing themselves. ${ }^{13}$

\footnotetext{
${ }^{11}$ It is hardly necessary to specify that here I use the word 'subject' in a general sense, as the technically philosophical notion of 'subject' was alien to Greek thought.

${ }^{12}$ It is only fair to recognize that we should not too quickly confuse the Aristotelian stance (as it has been interpreted here) and Biesta's vocabulary. The communion and the co-existence of which Aristotle speaks is rooted in a centrality of the self, which is what Biesta aims at dismantling through a Levinasian reversal. Just to pick out the most remarkable case: the Greek word for "desirable" comes from a verb which, originally, means "to take, to grasp" and, therefore, it has in it a 'prehensile' tonality which is not in keeping with Biesta's (2017a, pos. 598 ff.) view of what "desirable" means.

13 This will obviously not make it into "the other community" (if only because the other community' is precisely what cannot be 'made'). However, through this interpretation of the sumphilosophein, I am trying to explore the ways in which, while preserving the emphasis on
} 
One could argue that, while inspiring, the Lingisian view risks being too dichotomous. However, here I am not interested in pointing to the possibly onesided view of thinking-as-reason that underlies it, and, consequently, in reclaiming for CPI a status of thinking not 'infected' by the perils of the (rationalist) e-strangement implicit in Lingis' formulation. My strategy - in order to think with Biesta's ideas and not merely about them - has been rather that of letting the existential thrust of CPI emerge. As the "chronotope of sumphilosophein" (OLIVERIO, 2017) CPI is to be seen (also) in its experiential 'indexicality' and as a space of co-existence between friends, who are involved in thinking, understood not merely as an activity 'in the head' or an 'exercise of death,' but as one of the manners of being-together-in-the-world and enjoying friendship, 'aesthetically' sensing their presence with and to each other.

This argument should be complemented by one pivotal aspect: not only is P4wC to be construed as a "teaching movement" (BINGHAM, 2015; see also OLIVERIO [forthcoming/2018] for a more detailed discussion of this point), but the rediscovery of teaching in Biesta's terms could be conducive to an enriched way of looking at the role of the CPI 'facilitator' - all the more so in light of the interpretation advanced here of what doing philosophy together could mean. I would like to argue that the 'desirability' of that sense of oneself experienced through living-together in the form of the philosophizing-together requires a teacher who arouses in children a desire to exist in the world without being the centre of the world. ${ }^{14}$ However, an examination of this point would require a longer discussion than is possible here.

\footnotetext{
thinking and philosophy, we can respond to Biesta's concerns (about the activity within the CPI) as the following: "I have seen little that was explicitly experiential, that is, trying to make connections with children's experiences (not their ideas or their thinking), and have also seen little that provided opportunities for engagement beyond discussion and argumentation" (BIESTA, 2017b, p. 420). In the language of $\mathrm{P} 4 \mathrm{wC}$ scholarship we could state that CPI will remain just one more instance of the Lingisian rational community, if we limit ourselves to seeing (and practising) it as a "community of language" and a "community of mind" and if we forget that it is also a "community of gesture" and a "community of love" (KENNEDY, 1997).

${ }^{14}$ As I do not pursue any 'fusion of horizons' I admit that what I have in mind is an 'appropriation' of some of Biesta's insights within P4wC.
} 
We could approach the argument developed thus far from yet another angle. Heidegger (2002, p. 31) wrote about the stranglehold of reason on education that occurred with the Platonic paideia, which has been the (often repressed) assumption of most educational reflection since. Biesta's educational thinking can be seen as an attempt to overturn this Platonic heritage by educationally deploying some notions inspired by Levinas. Asking educational questions from "outside" philosophy could be read, accordingly, as the endeavour to set education free from the imperialism of (theory-oriented) philosophy, which tends to dissolve education in its own discourse.

We should be ready to recognize that, if CPI is ultimately the space of an intellectual and verbal play with concepts, significant as all this is, it may be in jeopardy of a Platonic drift, in which education turns into merely education for reason/critical thinking by finally confirming the dissolution of the 'educationality' of education, understood as subjectification (BIESTA, 2010, 2014, 2017a). While CPI might (and even could) not be the most adequate setting for the task of education in the Biestan understanding of it, it is not doomed, however, to be a Lingisian rational community, providing that it is the site in which the "polemic commonality of philosophy and education" (OLIVERIO, forthcoming/2017) happens time and again. By this phrase I try both to capture a genealogical event, namely the emergence of philosophy and education as inseparable but distinct twins after the "philosophical-educational Big Bang" (OLIVERIO, forthcoming/2017) at the dawn of Western tradition, and to highlight the need not to Platonically dissolve the former into the latter, making education just an "offshoot" of philosophy (BIESTA, forthcoming/2017).

What I would like to claim is that the narrative of a "philosophicaleducational Big Bang" is 'additional' to Lingis' and, to adopt Biesta's (2011, p. 307) aforementioned words, it "suggest[s] a perspective that can act as a reminder of a different way in which one can 'engage' with philosophy" within CPI, which offers a perspective different both from the imperialistic Platonic dissolution of education into philosophy (a tendency to which CPI as a merely rational 
community could very well capitulate) and from the Levinasian withdrawal from the emphasis on thinking.

I should specify once again that I am not presenting this as a synthesis, as if "the rational community" and "the other community" were aufgehoben in CPI so understood. More modestly, I am trying to think of ways of inhabiting CPI that reduce the risks of it turning into a rational community in which existence-in-theworld is bracketed and remains only 'in the head,' and in which education is just a function of philosophy. CPI can indeed become hospitable to experiences that "touch the soul" (BIESTA, 2017b, p. 432; 437), although I would not go so far as to say that CPI represents a privileged space in which these experiences can take place (a point magnificently made by Peter Shea [forthcoming/2018] in an essay which raises, from within the tradition of $P 4 w C$, some of the misgivings expressed by Biesta).

\section{concluding remarks}

In this response I have assumed the possibility of a dialogue between $\mathrm{P} 4 \mathrm{wC}$ and Biesta's educational thinking, and raised the question of what kind of dialogue it could be. I have excluded the possibility that this dialogue could lead to any "fusion of horizons," although I would tend to argue that there are some significant points of contact between the two educational stances in terms of 'themes,' of concerns about the contemporary dominant educational trends, and of the shared view that we should be committed to "making the practice and practicing of education itself more thoughtful" (BIESTA, 2017a, pos. 216). Moreover, I have endeavoured to verify this assumption - in an admittedly sketchy and only introductory way - by investigating what might represent a major bone of contention with Biesta, namely the intimate bond between philosophy and education, which is the very core of the P4wC approach and of its main educational 'device' (CPI).

Against this backdrop, I would like to suggest two ways in which we can frame the dialogue with Biesta, by capturing them in two phrases: 'parallel convergences' and 'bi-stable images.' The former is clearly an oxymoron, which 
gained an important meaning within the Italian political debate of the 1960s and 1970s. ${ }^{15}$ Independently from its historical origin, what strikes me in the phrase is the idea of a movement of converging that does not aim at any Aufhebung of the positions in a superior synthesis, because they are expected to remain, instead, in their 'face-to-face parallelism,' which only allows this kind of dialogue to continue to take place.

On the other hand, bi-stable images are those images - much studied by Gestaltpsychologie - in which the same sensorial stimulations are organized in two different figures (Gestalten) and the passing from one figure to the other (the Gestalt-switch) prevents one from being able to see the other one. In other words, either we see one figure or the other, because the perceptual structuration of the visual field impedes us from seeing the two contemporaneously. ${ }^{16}$

To return to my question: if we construe the dialogue with Biesta in terms of 'bi-stable images,' we recognize that there could be some commonalities in terms of themes, concerns and aspirations (i.e. the same sensorial stimulations of perceptual field) but we believe also that they are structured in such different educational stances (Gestalten) that a Gestalt-switch is necessary to see the alternative view. In that case it would be a matter of 'alternativeness' rather than 'additionality,' to appropriate Biesta's vocabulary. Judging from the title of Biesta's contribution to this issue of Childhood $\mathcal{E}$ Philosophy, this could be the way in which he might (sometimes) be inclined to interpret his dialogue with P4wC. ${ }^{17}$

Conversely, if we think in terms of "parallel convergences," by 'betting' upon the points of contact and encounter (in terms of themes, concerns and aspirations in reference to the dominant trends of contemporary educational

\footnotetext{
${ }^{15}$ In those two decades, amidst the divisions of the Cold War, it indicated the efforts to build agreed-upon policies on the part of Democrazia Cristiana (a centrist party) and the Partito Socialista. We should not misunderstand the idea of "parallel convergences" as an Italian form of Grosse Koalition. What was remarkable in the Italian political 'experiment' - at least as it was theorised - was that the convergences were not intended as a kind of constant 'ideological' rapprochement that could reduce the incommensurability of the two political cultures.

16 It should be noted that Gestaltpsychologie is as far from any kind of constructivism as possible. Therefore, when speaking of an organization/structuration of the perceptual field, this is not to be understood as an outcome of the 'epistemic' agency of the subject.

${ }^{17}$ However, as aforementioned (see fn. 4 and 5), the very conclusion of his article opens the door also to a kind of closeness to the 'logic' of "parallel convergences."
} 
parallel convergences: thinking with biesta about philosophy and education

scenarios), we might explore how we can 'indirectly' and 'additionally' contribute to each other in honing our conceptual and educational devices (convergences), by helping each other to see the common issues from another perspective, which will be all the more inspiring for the dialogue as long as it is not denied in its 'parallelism.'

\section{references}

BIESTA, G.J.J. (2006). Beyond Learning. Democratic Education for a Human Future. Boulder and London: Paradigm Publishers.

BIESTA, G.J.J. (2010). Good Education in an Age of Measurement. Ethics, Politics, Democracy. Boulder and London: Paradigm Publishers.

BIESTA, G.J.J. (2011). Philosophy, Exposure, and Children: How to Resist the Instrumentalisation of Philosophy in Education. In Journal of Philosophy of Education 45(2), 305-319.

BIESTA, G.J.J. (2014). The Beautiful Risk of Education. Boulder and London: Paradigm Publishers.

BIESTA, G.J.J. (2017a). The Rediscovery of Teaching. London and New York: Routledge. Kindle edition.

BIESTA, G.J.J. (2017b). Touching the Soul? Exploring an Alternative Outlook for Philosophical Work with Children and Young People. Childhood \& Philosophy 13(28), 415452.

BIESTA, G.J.J. (forthcoming/2017). What Shall We Do with the Children? In N. Levinson (ed.). Philosophy of Education Society Yearbook 2016.

BINGHAM, C 2015, 'Philosophy for Children as a Teaching Movement in an Era of too Much Learning', Childhood and Philosophy 11(22), pp. 223-240.

DERRIDA, J. (1979). The Parergon. Transl. C. Owens. In October, 9, 3-41.

HEIDEGGER, M. (2002). The Art of Teaching. Ed. and Trans. V. Allen \& A.D. Axiotis. In M.A. Peters (ed.), Heidegger, Education, and Modernity (pp. 27-45). Lanham-Boulder-New York-Oxford: Rowman \& Littlefield Publishers.

KENNEDY, D 1997, 'The Five Communities', Inquiry: Critical Thinking across Disciplines 16(4), 66-86.

LINGIS, A. (1994). The Community of Those Who Have Nothing in Common. Bloomington and Indianapolis: Indiana University Press.

OLIVERIO, S. (2012). Complex Thinking as Cosmopolitanism and the Drift of 'Learnification': P4C and Some Contemporary Challenges. In M. Santi \& S. Oliverio (eds.), Educating for Complex Thinking through Philosophical Inquiry. Models, Advances, and Proposals for the New Millennium (pp. 15-43). Napoli: Liguori.

OLIVERIO, S. (2017). Dimensions of the sumphilosophein. The Community of Philosophical Inquiry as a Palimpsest. In M. Gregory, J. Haynes, \& K. Murris (eds.), Routledge International Handbook of Philosophy for Children (pp. 93-100). London-New York: Routledge.

OLIVERIO, S. (forthcoming/2017). The Philosophical and Educational Big Bang. An Aristophanic-Deweyan Archaeology. In N. Levinson (ed.). Philosophy of Education Society Yearbook 2016.

OLIVERIO, S. (forthcoming/2018). The Teacher as Liberator: Ann Sharp between Philosophy of Education and Teacher Education. In M. Laverty \& M. Gregory (eds.), In 
Community of Inquiry with Ann Margaret Sharp: Philosophy, Childhood and Education. London-New York: Routledge.

ROTH, W.-M. (2011), Passibility. At the Limits of the Constructivist Metaphor, DordrechtHeidelberg-London- New York: Springer.

SHEA, P. (forthcoming/2018). Do we Put What Is Precious to Us at Risk through Philosophic Conversation? In M. Laverty \& M. Gregory (eds.), In Community of Inquiry with Ann Margaret Sharp: Philosophy, Childhood and Education. London-New York: Routledge.

received in: 12.08 .2017

accepted in: 30.08 .2017 